\title{
Babassu aqueous extract (BAE) as an adjuvant for T helper (Th)1-dependent immune responses in mice of a Th2 immune response-prone strain
}

\author{
Rosane NM Guerra ${ }^{1 *}$, Virgínia MG Silva², Luciana S Aragão-França², Pablo R Oliveira², Rodrigo Feitosa²,
} Flavia RF Nascimento ${ }^{1}$, Lain C Pontes-de-Carvalho ${ }^{2 *}$

\begin{abstract}
Background: The aqueous extract of a Brazilian palm-tree fruit - the babassu - (BAE) exerts a clear immunostimulative activity in vivo. In the present work, the possibility that BAE can promote Th1 immune responses in mice of a Th2 immune response-prone strain - the BALB/C was investigated. BAE itself, and preparations consisting of Leishmania amazonensis promastigote extract (LE), adsorbed or not to $\mathrm{Al}(\mathrm{OH})_{3}$, and in the presence or not of $\mathrm{BAE}$, were used as immunogens. $\mathrm{LE}$ and $\mathrm{Al}(\mathrm{OH})_{3}$ have been shown to preferentially elicit Th2 immune responses.

Results: The addition of BAE to LE-containing immunogenic preparations, adsorbed or not to $\mathrm{Al}(\mathrm{OH})_{3}$, clearly promoted the in vitro production of interferon $\gamma(\mathrm{IFN}-\gamma)$, a major Th1-dependent cytokine, and not of interleukin (IL-)4 (a Th2-dependent cytokine), by LE-stimulated splenocytes of immunized BALB/c mice. It also promoted the in vivo formation of IgG2a anti-LE antibodies. However, immunization with LE by itself led to an increased production of IL-4 by LE-stimulated splenocytes, and this production, albeit not enhanced, was not reduced by the addition of BAE to the immunogen. On the other hand, the IL-4 production by LE-stimulated splenocytes was significantly lower in mice immunized with a preparation containing $\mathrm{Al}(\mathrm{OH})_{3}$-adsorbed $\mathrm{LE}$ and $\mathrm{BAE}$ than in mice immunized with the control preparation of $\mathrm{Al}(\mathrm{OH})_{3}$-adsorbed LE without BAE. Moreover, an increased production of IFN- $\gamma$, and not of IL-4, was observed in the culture supernatants of splenocytes, from BAE-immunized mice, which were in vitro stimulated with BAE or which received no specific in vitro stimulus. No differences in IL-10 (an immunoregulatory cytokine) levels in the supernatants of splenocytes from mice that were injected with $B A E$, in relation to splenocytes from control mice, were observed. The spontaneous ex vivo production of NO by splenocytes of mice that had been injected with BAE was significantly higher than the production of NO by splenocytes of control mice.

Conclusions: Based on the results described above, BAE, or biologically active molecules purified from it, should be further investigated as a possible adjuvant, in association or not with aluminium compounds, for the preferential induction of Th1-dependent immune responses against different antigens in distinct murine strains and animal species.
\end{abstract}

\section{Background}

Th1-dependent immune responses have been shown to protect mammals against many clinically relevant intracellular pathogens, such as Mycobaterium tuberculosis, Leishmania sp., and human herpes virus, and even

\footnotetext{
* Correspondence: rnmguerra@pq.cnpq.br; lain@bahia.fiocruz.br

'Universidade Federal do Maranhão, Laboratory of Immunophysiology, São Luís, Brazil

${ }^{2}$ Centro de Pesquisa Gonçalo Moniz, Fundação Oswaldo Cruz, Salvador, Brazil Full list of author information is available at the end of the article
}

against some extracellular pathogens, such as Candida albicans [1-4]. Adjuvants for Th1 immune responses could be, therefore, crucial components of a vaccine against this type of pathogens $[5,6]$.

Different compounds have been tested for safety and adjuvant activity in human beings. Aluminum hydroxide, aluminum phosphate and Montanide ${ }^{\circledR}$, a new generation of water in oil emulsions, are still the only adjuvants licensed for use in humans [7-9]. Lack of detailed data on safety, dose and routes of immunization has restricted to

\section{() Biomed Central}


experimental animals the use of adjuvants that have been shown to be more potent or more directed to Th1 immune responses than the aluminum compounds [10-12].

The babassu (Orbignya phalerata, Mart, Arecaceae) is a palm tree commonly found in the northeast of Brazil. Babassu fruit flower is frequently used as food or folk medicine. Several important biological properties have been assigned to the babassu mesocarp flour, including an immunomodulatory activity [13]. It can increase the production of anti-insulin IgM antibodies in mice [14,15] and anti-thyroglobulin antibodies in rats [16]. In addition, the oral administration of an aqueous extract of babassu mesocarp to mice increased the production of inflammatory mediators (such as hydrogen peroxide, nitric oxide and TNF- $\alpha$ ) by peritoneal macrophages ex vivo and the influx of leukocytes to the peritoneal cavity [17]. These known immunostimulative effects of the babassu aqueous extract (BAE) have motivated the present investigation on its possible immunoadjuvant activity. Immunization protocols utilizing immunogenic preparations that were likely to induce polarized Th2-dependent immune responses, namely Leishmania promastigote extract $(\mathrm{LE})$ and $\mathrm{Al}(\mathrm{OH})$ 3 gel-adsorbed LE [18-20], were used. As described below, the injection of BAE preferentially stimulated the Th1 component of the anti-LE and the anti-BAE immune responses in the immunized mice.

\section{Results}

\section{Anti-LE antibody levels}

The addition of BAE to the antigenic preparations (both to $\mathrm{LE}$ or $\mathrm{Al}(\mathrm{OH})_{3}$ gel-adsorbed LE) led to significantly increased levels of serum anti-LE IgG2a antibodies in the immunized mice (Figure 1A, groups "LE + BAE" and "LE- $\mathrm{Al}(\mathrm{OH})_{3}+\mathrm{BAE}$ ") in relation to the corresponding control mice that did not receive BAE (Figure 1A, groups "LE" and "LE- $\mathrm{Al}(\mathrm{OH})_{3}$ "). The co-administration of BAE also led to a statistically significant increase in anti-LE IgG1 antibodies in the LE-immunized mice that have not received $\mathrm{Al}(\mathrm{OH})_{3}$ (Figure $1 \mathrm{~B}$, group " $\mathrm{LE}+$ BAE") in relation to the mice that were immunized only with LE, without adjuvants (Figure 1B, group "LE"). However, the addition of $\mathrm{BAE}$ to the $\mathrm{Al}(\mathrm{OH})_{3}$-adsorbed LE preparation led to a statistically significant decrease in IgG1 anti-LE antibody levels in the immunized mice (Figure $1 \mathrm{~B}$, group "LE- $\mathrm{Al}(\mathrm{OH})_{3}+\mathrm{BAE}$ "), in relation to the mice that were immunized with $\mathrm{Al}(\mathrm{OH})_{3}$-adsorbed $\mathrm{LE}$ without BAE (Figure $1 \mathrm{~B}$, group "LE- $\mathrm{Al}(\mathrm{OH})_{3}$ "). The results obtained with the use of BAE as adjuvant did not differ significantly from the results obtained with the use of CFA as adjuvant, both for IgG2a or IgG1 antibody levels (Figure 1). However, mice immunized with LE associated with both $\mathrm{BAE}$ and $\mathrm{Al}(\mathrm{OH})_{3}$ (Figure $1 \mathrm{~B}$, group "LE- $\mathrm{Al}(\mathrm{OH})_{3}+\mathrm{BAE}$ ") had significantly lower
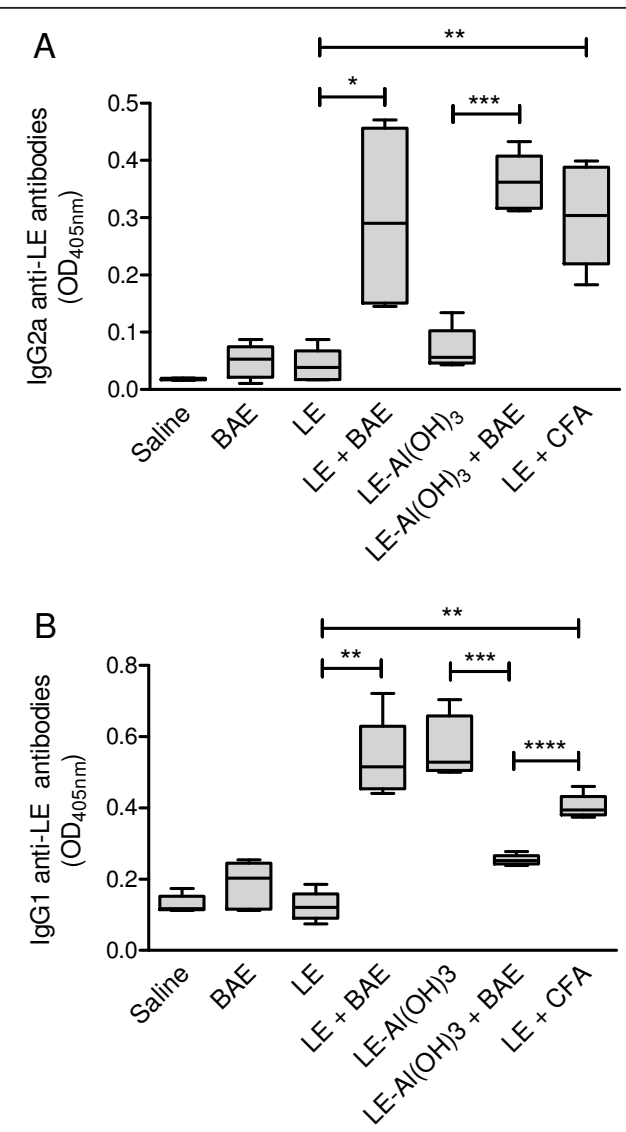

Figure 1 IgG1 and IgG2a anti-Leishmania promastigote extract (LE) antibody levels in mice immunized with $L E$, associated or not with babassu aqueous extract (BAE). IgG2a (A) and $\lg$ G1 (B) antibodies were detected by ELISA as detailed in the Material and Methods, in sera prepared from blood samples collected 10 days after the end of the immunization. Groups of five to eight $B A L B / c$ mice were immunized by two subcutaneous injections of $\mathrm{LE}$, associated with BAE (LE + BAE), or of $\mathrm{Al}(\mathrm{OH})_{3}$-adsorbed $\mathrm{LE}$, also associated with BAE (LE-AI(OH) $\left.)_{3}+\mathbf{B A E}\right), 14$ days apart. Groups of control mice were also immunized with LE emulsified in complete Freund's adjuvant (LE + CFA), with LE without BAE (LE), and with Al $(\mathrm{OH})_{3}$-adsorbed LE without BAE $\left(\mathrm{LE}-\mathrm{Al}(\mathrm{OH})_{3}\right)$, following the same immunization protocol. Each injection contained a total of $250 \mu \mathrm{g}$ of LE and/or $5 \mathrm{mg}$ of BAE. A negative control group was injected with a saline solution in place of the immunizing injections (Saline). The boxes represent the 10-90 percentile intervals and the median values of the results, and the vertical bars the value ranges. $P<$ 0.001 , Kruskal-Wallis test. ${ }^{*}, P \leq 0.007 ;{ }^{* *}, P \leq 0.003 ;{ }^{* * *}, P \leq 0.009$; ${ }^{* * * *}, P \leq 0.016$; Mann-Whitney $U$ test.

levels of anti-LE IgG1 antibodies than mice immunized with CFA-emulsified LE (Figure 1B, group "LE + CFA").

\section{Cytokine responses in non-stimulated and in LE- and BAE-stimulated cultures}

When stimulated in vitro with LE, the splenocytes from the mice that were immunized with LE and received BAE as adjuvant (Figure 2A group "LE + BAE") produced significantly higher concentrations of interferon $\gamma$ 
$(\mathrm{IFN}-\gamma)$ than the splenocytes from the mice that were immunized with LE without BAE (Figure 2A, group "LE"). The same result was observed when the mice were immunized with $\mathrm{Al}(\mathrm{OH})_{3}$-adsorbed $\mathrm{LE}$ and received $\mathrm{BAE}$ as adjuvant (Figure $2 \mathrm{~A}$, group " $\mathrm{LE}-\mathrm{Al}(\mathrm{OH})$ 3 + BAE"). When stimulated in vitro with LE, the splenocytes from these mice produced significantly higher concentrations of IFN- $\gamma$ than the splenocytes from mice that were immunized with $\mathrm{Al}\left(\mathrm{OH}_{3}\right.$ gel-adsorbed LE without BAE (Figure 2A, group "LE- $\left.\mathrm{Al}(\mathrm{OH})_{3}{ }^{\prime \prime}\right)$. The amounts of IFN- $\gamma$ produced by splenocytes of the mice that received $\mathrm{BAE}$, i.e., the mice that were immunized either with LE in the presence of BAE (Figure 2A, group "LE + BAE") or with $\mathrm{Al}(\mathrm{OH})_{3}$-adsorbed $\mathrm{LE}$ also in the presence of BAE (Figure 2A, group "LE-Al(OH) ${ }_{3}+$ BAE"), were comparable to those produced by splenocytes from the mice that were immunized with CFAemulsified LE (Figure 2A, group "LE + CFA"; $P>0.05$, Mann-Whitney U test).

The production of interleukin (IL-)4 by LE-stimulated splenocytes was either not altered by the addition of $\mathrm{BAE}$ to the immunogenic preparations (in the case of mice immunized with LE; Figure $2 B$, group "LE + BAE", $P>0.05$, Mann-Whitney $\mathrm{U}$ test), or was significantly reduced (in the case of mice immunized with $\mathrm{Al}(\mathrm{OH})_{3}$ gel-adsorbed LE; Figure 2B, group " $\mathrm{LE}-\mathrm{Al}(\mathrm{OH})_{3}+\mathrm{BAE}$, $P<0.001$, Mann-Whitney $U$ test), in relation to the corresponding control mice that did not receive $\mathrm{BAE}$ (Figure $2 \mathrm{~B}$, groups "LE" and "LE- $\mathrm{Al}(\mathrm{OH})_{3}$ ", respectively).

The production of IFN- $\gamma$, and not of IL-4, was significantly higher in BAE-stimulated cultures of splenocytes from BAE-immunized mice, than in splenocyte cultures from saline-treated control mice (Figure $3 \mathrm{~A}$ and $3 \mathrm{~B}$ ). Spleen cells from the mice that had been immunized with BAE spontaneously produced, ex vivo, more IFN- $\gamma$ than control saline-treated mice (Figure 3C). No statistically significant difference in the spontaneous production of IL-4 by splenocytes of BAE-immunized and saline-treated mice was observed (Figure 3D).

No statistically significant differences in IL-10 production by unstimulated, LE-stimulated, or BAE-stimulated splenocytes from the immunized and the non-immunized mice were observed (data not shown).

\section{Nitric oxide production}

The concentrations of nitric oxide in splenic cell supernatants from mice of the groups immunized with BAE or with BAE-containing preparations (Figure 4; groups "BAE", "LE + BAE", and $\left.\mathrm{LE}-\mathrm{Al}(\mathrm{OH})_{3}+\mathrm{BAE}\right)$ were significantly higher than in those from mice of the corresponding control groups, which were treated with saline only or immunized with preparations without BAE (Figure 4; groups "Saline", "LE", and $\mathrm{LE}-\mathrm{Al}(\mathrm{OH})_{3}$, respectively). The

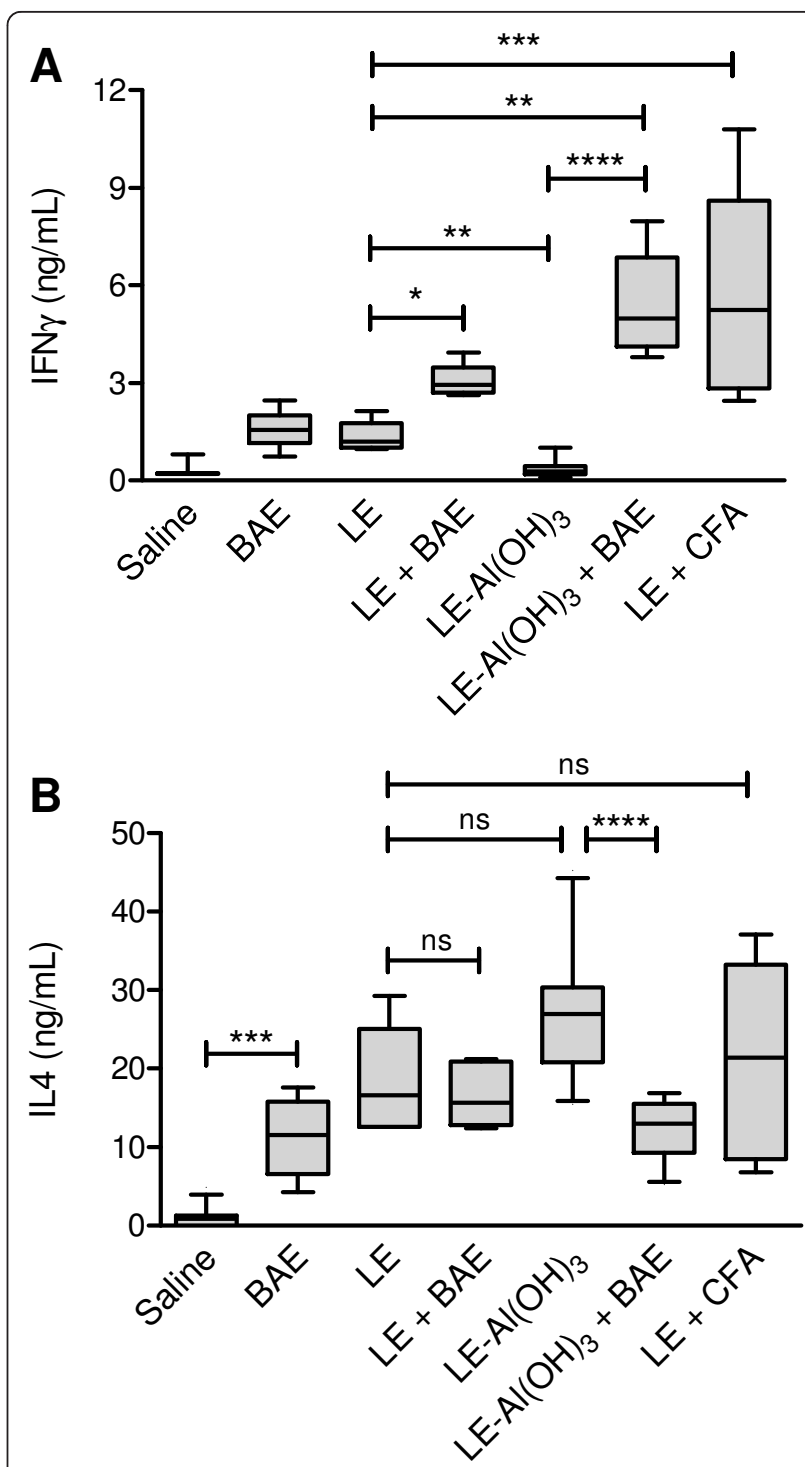

Figure 2 Concentrations of IFN $\gamma$ and IL-4 in the supernatants of splenocyte cultures from BALB/c mice immunized with Leishmania promastigote extract (LE), associated or not with babassu aqueous extract (BAE). Splenocytes (from spleens collected ten days after the end of the immunization) were stimulated with LE and concentrations of IFN $(\mathbf{A})$ and IL-4 (B) in the supernatants were measured by ELISA. Groups of five to 12 animals were immunized by two subcutaneous injections of $L E$, associated with $\mathrm{BAE}(\mathrm{LE}+\mathrm{BAE})$ or of $\mathrm{Al}(\mathrm{OH})_{3}$ gel-adsorbed $\mathrm{LE}$, also associated with BAE (LE-Al(OH $\left.)_{3}+\mathbf{B A E}\right), 14$ days apart. Groups of control mice were also immunized with LE emulsified in complete Freund's adjuvant (LE + CFA), with LE without BAE (LE), and with Al $(\mathrm{OH})_{3}$-adsorbed LE without BAE $\left(\mathbf{L E}-\mathbf{A l}(\mathbf{O H})_{3}\right)$, following the same immunization protocol. Each injection contained a total of $250 \mu \mathrm{g}$ of LE and/or 5 mg of BAE. A negative control group was injected with a saline solution in place of the immunizing injections (Saline). The boxes represent the 10-90 percentile intervals and the median values of the results, and the vertical bars the value ranges. $P<$ 0.001 , Kruskal-Wallis test. ${ }^{*}, P \leq 0.004 ;{ }^{* *}, P \leq 0.003$; ${ }^{* *}, P \leq 0.002$; ${ }^{* * * *}, P \leq 0.001 ; \mathrm{ns}$, non significant; Mann-Whitney $U$ test. 


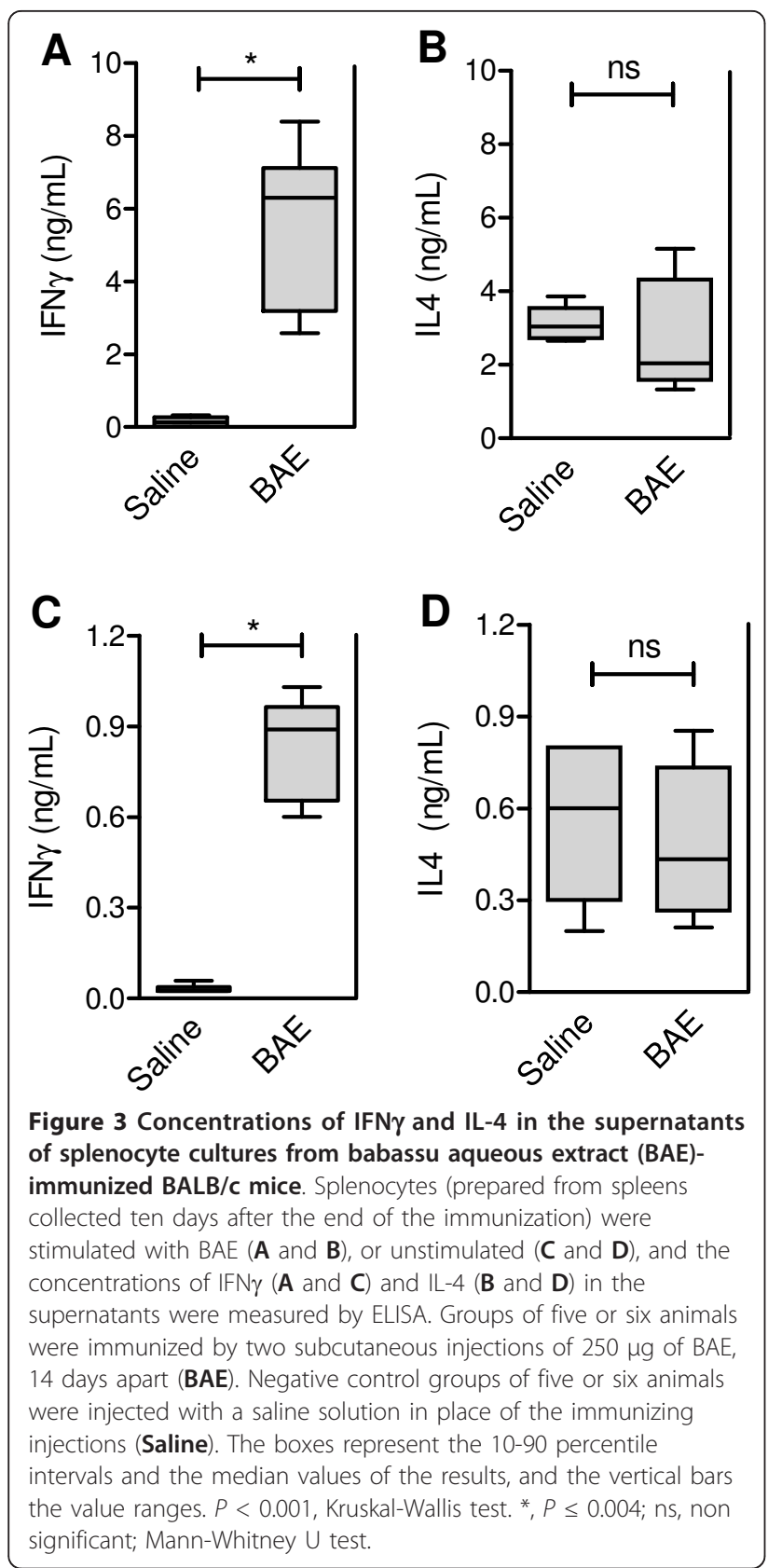

concentrations of nitric oxide in splenic cell supernatants from the positive control mice, which were immunized with CFA-emulsified LE (Figure 4; group "LE + CFA"), were also higher than the nitric oxide concentrations in splenic cell supernatants from mice of their corresponding control group (Figure 4; group "LE”).

\section{Discussion}

The purpose of this study was to investigate the efficacy, as immunological adjuvant, of an aqueous extract of the babassu mesocarp. This adjuvant activity was investigated with the BAE in two different formulations: in

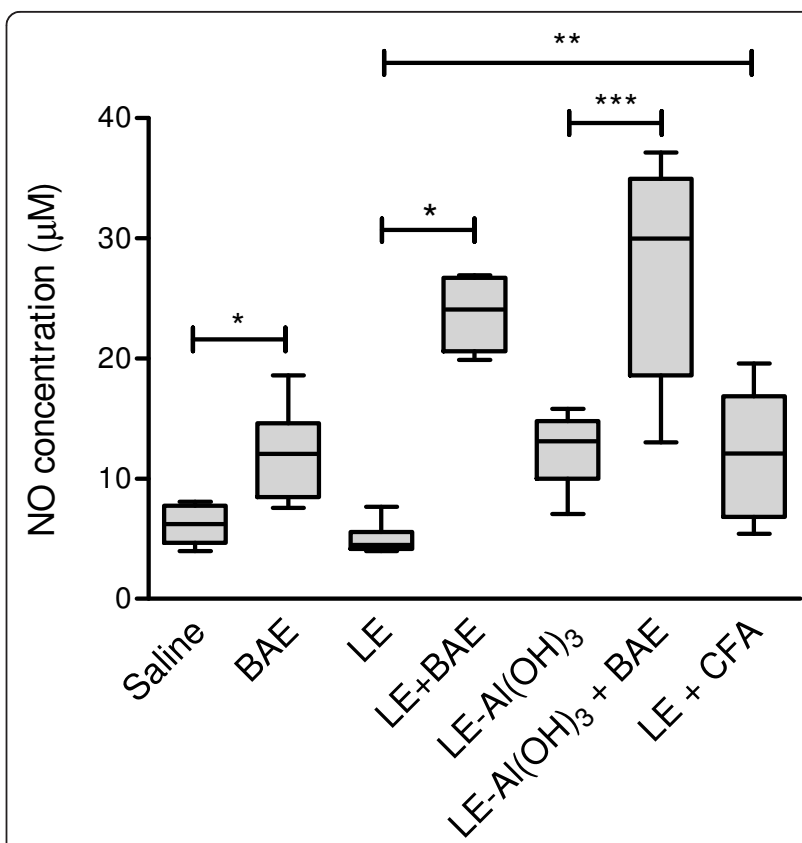

Figure 4 Nitric oxide concentration in splenocyte cultures from mice immunized with Leishmania promastigote extract (LE) and babassu aqueous extract (BAE). Supernatants were obtained from unstimulated spleen cells, i.e, spleen cells that were not incubated with antigen in vitro. Spleens were collected ten days after the end of the immunization from groups of five to nine $B A L B / C$ mice that had been immunized with two subcutaneous injections of $\mathrm{LE}$ associated with BAE (LE + BAE) or of $\mathrm{Al}(\mathrm{OH})_{3^{-}}$ adsorbed $L E$ associated with BAE (LE-AI(OH $\left.)_{3}+\mathrm{BAE}\right), 14$ days apart. Groups of control mice were also immunized with LE emulsified in complete Freund's adjuvant (LE + CFA), with LE without BAE (LE), and with $\mathrm{Al}(\mathrm{OH})_{3}$-adsorbed LE without BAE (LE-AI $(\mathrm{OH})_{3}$ ), following the same immunization protocol. Each injection contained a total of $250 \mu \mathrm{g}$ of LE and/or $5 \mathrm{mg}$ of BAE. A negative control group was injected with a saline solution in place of the immunizing injections (Saline). The boxes represent the 10-90 percentile intervals and the median values of the results, and the vertical bars the value ranges. $P<0.001$, Kruskal-Wallis test. ${ }^{*}, P \leq$ $0.003 ;{ }^{* *}, P \leq 0.005 ;{ }^{* * *}, P \leq 0.016$; Mann-Whitney $\cup$ test.

soluble form or adsorbed to $\mathrm{Al}(\mathrm{OH})_{3}$. In both cases, its injection in mice stimulated a Th1-dependent immune response, both to itself or to LE, as demonstrated by: (i) a marked increase in circulating anti-LE IgG2a antibodies; (ii) an increased in vitro production of IFN- $\gamma$ by LE-or BAE-stimulated splenocytes; (iii) an increased $e x$ vivo production of IFN- $\gamma$ by unstimulated splenocytes, and (iv) an increased ex vivo production of nitric oxide by splenic cells. As expected, the immunization of $\mathrm{BALB} / \mathrm{c}$ mice with LE alone led to the significant production of IL-4 by LE-stimulated splenocytes [18]. The addition of BAE to the LE did not significantly augment this IL-4 production. This finding, therefore, does not support the possibility that, in addition to promoting Th1 immune responses, the BAE also enhances Th2 immune responses. On the other hand, a reduction in 
IL-4 production by the antigen-stimulated splenocytes, which could be expected from a Th1-polarising adjuvant, was not seen in these mice. However, additional results indicate that the $\mathrm{BAE}$ does preferentially enhance Th1 immune responses, and even reduces a Th2dependent immune response. First, the addition of BAE to the immunogenic preparation significantly reduced the production of IL-4 by splenocytes from mice immunized with $\mathrm{Al}(\mathrm{OH})_{3}$-adsorbed LE. The reason why it would exert this inhibitory effect on the IL-4 production only when the anti-LE immune response is concomitantly stimulated by $\mathrm{Al}(\mathrm{OH})_{3}$ is not clear. It would not be surprising, however, that the $\mathrm{LE}$ and the $\mathrm{Al}(\mathrm{OH})_{3}$ would promote $\mathrm{Th} 2$ immune responses through different mechanisms, and it is possible that the $\mathrm{Al}(\mathrm{OH})_{3}$-induced mechanism could be more easily inhibited by immune manipulation than the LEinduced mechanism. Second, in mice injected with BAE alone, a recall immune response to antigens that were present in the BAE was observed. This response was characterized by significantly increased production of IFN- $\gamma$, and no significant differences in IL-4 production, by the mouse splenocytes when they were subjected to stimulation with BAE in vitro, in relation to the splenocytes of saline-injected control mice. An IFN- $\gamma$ response was already significantly taking place in vivo, since splenocytes from the BAE-immunized mice spontaneously produced significant amounts of IFN- $\gamma$, and not of IL-4, ex vivo, in relation to splenocytes from control, saline-treated mice.

No differences in IL-10 levels in the supernatants of splenocytes from mice that were injected with BAE, in relation to splenocytes from control mice, were observed. This finding, which indicates that BAE is not inducing leukocytes to produce IL-10, could perhaps contribute to the stimulative effect of BAE on IFN- $\gamma$ producing immune responses, since IL-10 would tend to down regulate those immune responses [21].

The addition of BAE to the LE preparation also led to an increased production of IgG1 antibodies, apparently conflicting with the absence of increased IL-4 production by in vitro-stimulated splenocytes. However, IgG1 antibodies in mice have been shown to constitute two different molecular sub-populations, one which can sensitize mast cells and is dependent on IL-4 for its production, and another that does not bind to mast cells and depends on the Th1-inducing IL-12 cytokine to be produced $[22,23]$. Thus, whereas the presence of IgG2a antibodies can be considered a marker of an IFN- $\gamma$ producing Th1 immune response in most mouse strains, including the $\mathrm{BALB} / \mathrm{c}[24,25]$, the implication of the presence of IgG1 antibodies, in terms of the nature of the underlying immune response, is much less clear.

In this study, the Th1 immune response-promoting activity of BAE was shown in mice of the BALB/c strain, which are Th2-biased [26]. It could be expected, therefore, that the Th1-promoting effect would be even more pronounced in other strains of mice.

Aluminium compounds are the most widely employed adjuvants for human beings [27]. Their effectiveness is associated with a deposit formation in the site of administration [28-30]. The mechanism responsible for the adsorption of antigenic proteins to aluminium adjuvants involves electrostatic forces and hydrophobic interactions, among other physicochemical phenomena [20]. However, the use of aluminium compounds as adjuvants is limited by their failure to stimulate cellular immune responses, including those mediated by cytotoxic $\mathrm{T}$ cells $[19,20]$. These compounds are known to induce a Th2 rather than Th1 immune responses [28-30], whereas CFA, not licensed for use in human beings, usually induces a mixed Th1-Th2 response [19,31]. These properties were confirmed in the present work.

The protective responses against some intracellular pathogens, such as Leishmania and Mycobacterium, are mediated by Th1 cells, both in mice $[10,32]$ and in human beings $[1,4]$. There is, therefore, a need for highly efficacious, atoxic, Th1-promoting adjuvants, to be used in vaccine preparations against these and other pathogens. The Th1 cytokine profile induced by BAE qualifies it as a promising candidate to become one of these adjuvants. Indeed, the use of BAE as adjuvant led to increased in vitro production of IFN- $\gamma$ and nitric oxide by splenocytes, and both these biologically active molecules have been shown to be positively involved in the intracellular killing of Leishmania and Mycobacterium [33,34]. In the case of Leishmania, however, the present results suggest that particular parasite antigens that do not induce Th2 immune responses, either by their intrinsic nature or by amino-acid sequence manipulation, should be used.

Advantages of the BAE, when compared with other adjuvants, include the ample availability of the babassu mesocarp, and its low cost of manufacture and ease of formulation. The data presented herein justifies further studies to identify the biologically active molecule(s) in the BAE. Since Th1 cytokines may inhibit the development of Th2 immune responses [32], the induction of Th1 immune responses by BAE may therefore also be useful in the control of diseases that are mediated by Th2 immune responses, such as allergic asthma and rhinitis.

\section{Conclusions}

Based on the present findings, it was possible to conclude that: (i) BAE promotes preferentially a Th1-dependent immune response in a Th2-prone strain of mice; (ii) BAE, and/or biologically active molecules derived from it, deserve to be further investigated as possible adjuvants in candidate vaccines for leishmaniases and 
other diseases caused by intracellular pathogens, and possibly in the immunotherapy of diseases that are mediated by Th2 immune responses, such as allergic asthma and rhinitis.

\section{Methods}

Mice

Male, 8-12 week-old Balb/c mice, weighing 20-25 g, were from the Animal Breeding Unit of the Oswaldo Cruz Foundation, Salvador, Brazil. The animals were kept in ventilated cages, at $23 \pm 1^{\circ} \mathrm{C}$, with a relative humidity of 44-56\%, and light and dark cycles of $12 \mathrm{~h}$. They had free access to sterilized food and water. All procedures involving the animals were reviewed and approved by the institutional Ethics Committee in Experimental Animal Use, in accordance with the Brazilian College of Animal Experimentation.

\section{Babassu and Leishmania extracts}

Babassu mesocarp flour was purchased from ASSEMA (São Luís, Maranhão, Brazil). This product was subjected to analysis of authenticity, integrity and purity, by physicochemical tests, including standard chromatographic techniques. Similarities in all physicochemical aspects were observed when it was compared with a mesocarp flour prepared in our laboratory [17] from babassu fruits collected from Pedreiras, State of Maranhão, Brazil (authenticated voucher specimen number 1135, filed in the Herbario Ático Seabra, São Luís, State of Maranhão, Brazil).

Eighty grams of the mesocarp flour were extracted during $1 \mathrm{~h}$ with $1 \mathrm{~L}$ of sterilized water, at $24^{\circ} \mathrm{C}$, under constant stirring. The aqueous extract was filtered in $0.22-\mu \mathrm{m}$ Millipore ${ }^{\mathrm{TM}}$ units and then diluted in $0.15 \mathrm{M}$ phosphate-buffered saline, pH 7.2 (PBS), or culture medium, to the appropriate concentrations for the in vivo and in vitro studies. The composition of the extract, as measured by high-pressure liquid chromatography and gaseous chromatography, was: polysaccharides, 94.5\%; proteins, $2.2 \%$; lipids, $0.5 \%$; monosaccharides and disaccharides, $1.8 \%$; amino acids, $<1.0 \%$.

Promastigotes from the MHOM/Br87/Ba125 L. amazonensis strain, derived from tissue amastigotes, were cultured at $23^{\circ} \mathrm{C}$ in Schneider's medium (Sigma-Aldrich Co., Saint Louis, MO, USA), pH 7.2, supplemented with 50 $\mu \mathrm{g} / \mathrm{mL}$ of gentamycin and $10 \%$ of heat-inactivated fetal bovine serum (FBS; HIFCS, Gibco Laboratories, Grand Island, NY, USA). To prepare the LE, promastigotes were washed three times in ice-cold sterile saline, resuspended in ice-cold saline and lysed by exposition to ultrasound $(10 \times 1$-min cycles on ice). The lysates were centrifuged at $16,000 \mathrm{~g}$ for 10 minutes at $4{ }^{\circ} \mathrm{C}$, the supernatants filtered on membranes with $0.22 \mu \mathrm{m}$-diameter pores (Millipore, São Paulo, Brazil) and immediately stored at $-70^{\circ} \mathrm{C}$ in small aliquots. Their protein content was determined by Lowry's method [35].

\section{Immunizations}

$\mathrm{Al}(\mathrm{OH})_{3}$ gel (Alhydrogel; Sigma-Aldrich Co., Poole, UK), at $1.3 \mathrm{mg} / \mathrm{mL}$, was mixed with an equal volume of a solution containing $\mathrm{LE}(3.5 \mathrm{mg} / \mathrm{mL})$ and BAE $(80 \mathrm{mg} / \mathrm{mL})$, incubated at room temperature for 20 minutes and vortexed before utilization. Groups of 5 to 9 animals were immunized by two subcutaneous injections of the $\mathrm{Al}$ $(\mathrm{OH})_{3}$ gel-adsorbed extracts, separated by a two-week interval. Groups of 5-9 mice were also immunized, using the same protocol, with LE emulsified in complete Freund's adjuvant (CFA; $1 \mathrm{mg} / \mathrm{mL}$ of Mycobacterium tuberculosis, Sigma-Aldrich Co., Poole, UK), with LE mixed with $\mathrm{BAE}$ without $\mathrm{Al}(\mathrm{OH})_{3}$ gel, with $\mathrm{Al}(\mathrm{OH})_{3}$ geladsorbed LE without BAE, and with BAE. The amounts of LE and BAE in each injection were always $250 \mu \mathrm{g}$ and $5 \mathrm{mg}$, respectively. A negative control group was injected with the diluent (saline) solution in place of the immunizing injections.

\section{Determination of antibody levels}

Serum samples were prepared from blood collected ten days after the last antigen or saline injection, for determination of anti-LE IgG1 and IgG2a antibody levels by ELISA, as described previously [36]. Briefly, LE was diluted to a concentration of $40 \mu \mathrm{g} / \mathrm{mL}$ in carbonatebicarbonate buffer ( $\mathrm{pH}$ 9.6) and adsorbed onto wells of flat-bottomed ELISA strips (NUNC, Roskilde, Denmark) by overnight incubation at $4^{\circ} \mathrm{C}$. The wells were then washed five times with PBS containing $0.05 \%$ of Tween 20 (PBS-T) and incubated with PBS-T containing 1\% bovine serum albumin (PBS-TA) for $1 \mathrm{~h}$ at $37^{\circ} \mathrm{C}$. Another wash as the described above was followed by the addition of a $1 / 100$ dilution of mouse sera in PBSTA. After $30 \mathrm{~min}$ at $37^{\circ} \mathrm{C}$ and further washing, $100 \mu \mathrm{L}$ of peroxidase-conjugated goat anti-mouse IgG1 or IgG2a (PharMingen, San Diego, CA, USA), diluted 1:1000 in PBS-TA, were added to the wells and incubated for $1 \mathrm{~h}$ at $37^{\circ} \mathrm{C}$. The wells were then washed five times with PBS-T and the colour was developed by adding $100 \mu \mathrm{L}$ of a solution of tetramethylbenzidine and $\mathrm{H}_{2} \mathrm{O}_{2}$ and incubating in the dark for $20 \mathrm{~min}$. The reaction was stopped with $2 \mathrm{~N} \mathrm{H}_{2} \mathrm{SO}_{4}$ and the optical density (OD) for $450 \mathrm{~nm}$ wave-length light was measured.

\section{Cytokine quantification in spleen-cell cultures}

Spleens were aseptically removed 10 days following the booster. Cell suspensions were prepared by gently teasing apart the splenic tissue in RPMI 1640 supplemented with $2 \mathrm{mM}$ L-glutamine, $100 \mathrm{U} / \mathrm{ml}$ penicillin, $100 \mu \mathrm{g} / \mathrm{mL}$ streptomycin, $0.05 \mathrm{mM}$ 2-mercaptoethanol, and 10\% FBS (Life Technologies, Paisley, UK). Viable cells were enumerated 
in a Trypan blue exclusion assay. Cytokine production was assessed by culturing splenocytes $\left(10^{6} / \mathrm{mL}\right)$ in 24-well flatbottom tissue culture plates (Costar, Cambridge, MA, USA). All samples were incubated in duplicate $(500 \mu \mathrm{L} /$ well) with LE (40 $\mu \mathrm{g} /$ well $)$ or BAE $(50 \mu \mathrm{g} /$ well $)$ or with RPMI 1640 medium alone. Supernatants were harvested after 24 and $48 \mathrm{~h}$ incubation at $37^{\circ} \mathrm{C}$ and $5 \% \mathrm{CO}_{2}$, and stored at $-20^{\circ} \mathrm{C}$ until assayed. IFN- $\gamma$, IL-4, and IL-10 were quantified by commercial capture ELISA kits, according to the manufacturer's directions (eBiosciences, San Diego, CA, USA). The detection limits of the ELISAs were $2 \mathrm{pg} / \mathrm{mL}$ for IFN- $\gamma$ and IL-4, and $4 \mathrm{pg} / \mathrm{mL}$ for IL- 10 . Cytokine concentrations in the cell culture supernatants were determined by interpolation of the obtained ODs (for $492 \mathrm{~nm}$-wave length light) values in cytokine standard curves (which had $r \geq 0.99$ ).

\section{Nitric oxide concentration}

Fifty- $\mu \mathrm{L}$ volumes of supernatants from unstimulated splenocytes, incubated for 24 hours in vitro at $37^{\circ} \mathrm{C}, 5 \%$ of $\mathrm{CO}_{2}$ atmosphere and cell density of $5.2 \times 10^{6} / \mathrm{mL}$, were collected and incubated with an equal volume of Griess reagent ( $1 \%$ sulfanilamide, $0.1 \%$ naphthalene diaminedihydrochloride, $2.5 \% \mathrm{H}_{3} \mathrm{PO}_{4}$ ) for $10 \mathrm{~min}$ at room temperature, to allow the accumulation of nitrite (a stable end product of the NO reaction) [37]. The absorbance of $550 \mathrm{~nm}$ wave-length light was determined. Conversion of absorbance to $\mu \mathrm{M}$ of $\mathrm{NO}$ was done by interpolation into a standard curve obtained with known concentrations (5$60 \mu \mathrm{M})$ of sodium nitrite in RPMI medium.

\section{Statistical analysis}

The statistical significances of differences among experimental groups were determined, with the use of the SPSS Statistics 17.0 program, by the Kruskal-Wallis and Mann-Whitney $U$ tests for whole experimental results and pairwise comparisons, respectively. Values were considered statistically significant when $P \leq 0.05$.

\section{Acknowledgements}

This work was supported by the Conselho Nacional de Desenvolvimento Científico e Tecnológico - CNPq, Brazil (grant nº 478351/2006-2); RNMG was supported by post-doc fellowship from CNPq (grant n¹50677/2005-7).

\section{Author details}

'Universidade Federal do Maranhão, Laboratory of Immunophysiology, São Luís, Brazil. ${ }^{2}$ Centro de Pesquisa Gonçalo Moniz, Fundação Oswaldo Cruz, Salvador, Brazil.

\section{Authors' contributions}

All authors carried out experimental procedures, interpreted the results and/ or helped to draft the manuscript. All authors read and approved the final manuscript.

Received: 19 October 2010 Accepted: 29 January 2011 Published: 29 January 2011
References

1. Carvalho EM, Barral A, Pedral-Sampaio D, Barral-Netto M, Badaró R, Rocha H, Johnson WD Jr: Immunologic markers of clinical evolution in children recently infected with Leishmania donovani chagasi. J Infect Dis 1992, 165:535-540.

2. Romani $L$, Puccetti $P$, Bistoni $F$ : Biological role of Th cell subsets in candidiasis. In Th1 and Th2 cells in health and disease. Edited by: Romagnani S, Farmington, CT. Karger; 1996:114-137.

3. Koelle D, Corey L: Recent progress in herpes simplex virus immunobiology and vaccine research. Clin Microbiol Rev 2003, 16:96-113.

4. Almeida AS, Lago PM, Boechat N, Huard RC, Lazzarini LC, Santos AR, Nociari M, Zhu H, Perez-Sweeney BM, Bang H, Ni Q, Huang J, Gibson AL, Flores VC, Pecanha LR, Kritski AL, Lapa e Silva JR, Ho JL: Tuberculosis is associated with a down-modulatory lung immune response that impairs Th1-type immunity. J Immunol 2009, 183:718-731.

5. Ravindran R, Bhowmick S, Das A, Ali N: Comparison of BCG, MPL and cationic liposome adjuvant systems in leishmanial antigen vaccine formulations against murine visceral leishmaniasis. BMC Microbiol 2010, 10:181.

6. Kim D, Rhee JW, Kwon S, Kim YE, Choi SY, Park J, Lee Y, Kwon HJ: Enhancement of immunomodulatory activity by liposome-encapsulated natural phosphodiester bond CpG-DNA in a human B cell line. BMB Rep 2010, 43:250-256.

7. Petrovsky N, Aguilar JC: Vaccine adjuvants: current state and future trends. Immunol Cell Biol 2004, 82:488-496.

8. Campos-Neto A: What about Th1/Th2 in cutaneous leishmaniasis vaccine discovery? Braz J Med Biol Res 2005, 38:979-984.

9. Aucouturier J, Dupuis L, Deville S, Ascarateil S, Ganne V: Montanide ISA 720 and 51: a new generation of water in oil emulsions as adjuvants for human vaccines. Expert Rev Vaccines 2002, 1:111-118.

10. Cote-Sierra J, Bredan A, Toldos CM, Stijlemans B, Brys L, Cornelis P, Segovia M, De Baetselier $P$, Revets $H$ : Bacterial lipoprotein-based vaccines induce tumor necrosis factor-dependent type 1 protective immunity against Leishmania major. Infect Immun 2002, 70:240-248.

11. Jaafari MR, Badiee A, Khamesip A, Samiei A, Soroush D, Masoumeh TK, Barkhordari F, Mcmaster WR, Mahboudi F: The role of CpG ODN in enhancement of immune response and protection in BALB/C mice immunized with recombinant major surface glycoprotein of Leishmania (rgp63) encapsulated in cationic liposome. Vaccine 2007, 25:6107-6117.

12. Moreno J, Nieto J, Masina S, Cafiavate C, Cruz I, Chicharro C, Carrillo E, Napp S, Reymond C, Kaye PM, Smith DF, Fasel N, Alvar J: Immunization with $\mathrm{H1}, \mathrm{HASPB} 1$ and MML Leishmania proteins in a vaccine trial against experimental canine leishmaniasis. Immunization with H1, HASPB1 and MML Leishmania proteins in a vaccine trial against experimental canine leishmaniasis. Vaccine 2007, 25:5290-5300.

13. Silva BP, Parente JP: An anti-inflammatory and immunomodulatory polysaccharide from Orbignya phalerata. Fitoterapia 2001, 72:887-893.

14. Guerra RNM, Barroqueiro ESB, Chagas AP: Increase of self-antibodies and glucose levels in mice treated with babassu (Orbignya phalerata). Scand J Immunol 2001, 54(Suppl):66.

15. Barroqueiro ESB, Chagas AP, Nascimento FRF, Guerra RNM: B cell, macrophage activation and the diabetogenic effect of babassu mesocarp. Rev Bras Med Trop 2001, 34(Suppl):72.

16. Gaitan E, Cooksey RC, Legan J, Day RH, Ingbar SH, Medeiros-Neto G: Antithyroid effects in vivo and in vitro of babassu and mandioca: a staple food in goiter areas of Brazil. Eur J Endocrynol 1994, 131:138-144.

17. Nascimento FRF, Barroqueiro ESB, Azevedo APS, Lopes AS, Ferreira SCP, Silva LS, Maciel MCG, Rodriguez D, Guerra RNM: Macrophage activation induced by Orbignya phalerata (babassu). J Ethnopharmacol 2006, 103:53-58.

18. Yamakami K, Akao S, Sato M, Nitta Y, Miyazaki J, Tadakuma T: A single intradermal administration of soluble leishmanial antigen and plasmid expressing interleukin-12 protects BALB/c mice from Leishmania major infection. Parasitol Int 2001, 50:81-91.

19. Shibaki A, Katz SI: Induction of skewed Th1/Th2 T-cell differentiation via sub cutaneous immunization with Freund's adjuvant. Exp Dermatol 2002, 11:126-134.

20. Lindblad EB: Aluminum adjuvants-in retrospect and prospect. Vaccine 2004, 22:3658-3668.

21. Sundstedt A, Höiden I, Rosendahl A, Kalland T, van Rooijen N, Dohlsten M: Immunoregulatory role of IL-10 during superantigen-induced hyporesponsiveness in vivo. J Immunol 1997, 158:180-186. 
22. Faquim-Mauro EL, Coffman RL, Abrahamsohn IA, Macedo MS: Cutting edge: mouse $\lg \mathrm{G} 1$ antibodies comprise two functionally distinct types that are differentially regulated by IL-4 and IL-12. J Immunol 1999, 163:3572-3576.

23. Faquim-Mauro EL, Macedo MS: Induction of IL-4-dependent, anaphylactictype and IL-4-independent, non-anaphylactic-type IgG1 antibodies is modulated by adjuvants. Int Immunol 2000, 12:1733-1740.

24. Snapper CM, Paul WE: Interferon-gamma and B cell stimulatory factor-1 reciprocally regulate lg isotype production. Science 1987, 236:944-947.

25. Martin RM, Lew AM: Is IgG2a a good Th1 marker in mice? Immunol Today 1998, 19:49.

26. Jyonouchi H, Sun S, Winship T, Kuchan MJ: Dietary ribonucleotides increase antigen-specific type $1 \mathrm{~T}$-helper cells in the regional draining lymph nodes in young BALB/cJ mice. Nutrition 2003, 19:68-69.

27. Brewer JM: (How) do aluminium adjuvants work? Immunol Lett 2006 102:10-15.

28. Brewer JM, Conacher M, Hunter CA, Mohrs M, Brombacher F, Alexander J: Aluminium hydroxide adjuvant initiates strong antigen-specific Th2 responses in the absence of IL-4- or IL-13 mediated signaling. J Immunol 1999, 163:6448-6454.

29. Cox JC, Coulter AR: Adjuvants - a classification and review of their modes of action. Vaccine 1997, 15:248-256.

30. Lindblad EB: Aluminium compounds for use in vaccines. Immunol Cell Biol 2004, 82:497-505.

31. Oscherwitz J, Hankenson FC, Yu F, Cease KB: Low-dose intraperitoneal Freund's adjuvant: toxicity and immunogenicity in mice using an immunogen targeting amyloid-beta peptide. Vaccine 2006, 24:3018-3025.

32. Alexandre J, Bryson K: T helper (Th)1/Th2 and Leishmania: paradox rather than paradigm. Immunology Letters 2005, 99:17-23.

33. Green SJ, Nacy CA, Meltzer MS: Cytokine-induced synthesis of nitrogen oxides in macrophages: a protective host response to Leishmania and other intracellular pathogens. J Leukoc Biol 1991, 50:93-103.

34. Denis M: Interferon-gamma-treated murine macrophages inhibit growth of tubercle bacilli via the generation of reactive nitrogen intermediates. Cell Immunol 1991, 132:150-157.

35. Lowry OH, Rosenbrough NJ, Faar AL, Randall RJ: Protein measurement with the folin phenol reagent. J Biol Chem 1951, 193:265-275.

36. Johnstone A, Thorpe R: Immunoassays. In Immunochemistry in Practice. 2 edition. Edited by: Johnstone A, Thorpe R. London: Blackwell Scientific Publications; 1987:241-260.

37. Ding $A H$, Nathan $C F$, Stueur DJ: Release of reactive nitrogen intermediates and reactive oxygen intermediates from mouse peritoneal macrophages. Comparison of activating cytokines and evidence for independent production. J Immunol 1988, 141:2407-2412.

doi:10.1186/1471-2172-12-13

Cite this article as: Guerra et al:: Babassu aqueous extract (BAE) as an adjuvant for $\mathrm{T}$ helper (Th)1-dependent immune responses in mice of a Th2 immune response-prone strain. BMC Immunology 2011 12:13.

\section{Submit your next manuscript to BioMed Central and take full advantage of:}

- Convenient online submission

- Thorough peer review

- No space constraints or color figure charges

- Immediate publication on acceptance

- Inclusion in PubMed, CAS, Scopus and Google Scholar

- Research which is freely available for redistribution

Submit your manuscript at www.biomedcentral.com/submit
Biomed Central 